\title{
Development of Physical Test Application Model
}

\author{
Iyakrus $^{1}$, Tono Sugihartono ${ }^{2}, \operatorname{Hartati}^{3}, \mathrm{Meirizal}^{4}, \mathrm{Arizky}^{5}$ \\ \{iyakrus@fkip.unsri.ac.id ${ }^{1}$, sugiartono@unib.ac.id ${ }^{2}$, hartati@ fkip.unsri.ac.id ${ }^{3}$ \} \\ Sriwijaya University, Palembang, Indonesia ${ }^{1,3}$ \\ Bengkulu University, Bengkulu, Indonesia ${ }^{2}$
}

\begin{abstract}
This study aims: 1) to produce a valid physical test application model, 2) to determine the effectiveness of the physical test application model 3) to determine the physical abilities of athletes through the physical test application model. This research is a research development (Research \& Development) in the form of a physical test application model with the following procedures: (1) product analysis, (2) developing the initial product (3) perform a expert validation (4) perform a small-scale and large-scale field trials (5) product revision and (6) final product. The test subjects in this study were 65 athletes from South Sumatra. Data analysis was carried out by descriptive qualitative and quantitative. The results of this study produce a physical test application model that is valid, effective and practical. It is recommended for trainers and teachers to use this physical test application model as an alternative in measuring the physical abilities of athletes.
\end{abstract}

Keywords: Model, application, physical test.

\section{Introduction}

The 21st century is a digital era, this can be seen from the rapid development of technology that aims to solve problems that exist in all fields of science including sports science [1]. Sport science is one of the fields of science that cannot be separated from the use of technology, one of which is for testing and measurement activities [2]. Testing and measurement is useful for aptitude tests and sports development which focus on three aspects including physical ability, mental ability and social traits [3]. Another function of testing and measurement in sports is to determine the level of activity or physical activity of a person, especially in athletes [4].

Excellent physical ability is important for an athlete, so it is necessary to know the athlete's physical fitness which includes speed, muscle strength, agility, flexibility, muscle strength and endurance [5] [6]. The physical test can be done by utilizing technology by developing a special application model for the physical test. Through this physical test application model, it will reduce the error rate in managing test data, make the test committee more effective and efficient in obtaining objective and valid data [7].

According to the author's observations, the physical test for PON 2021 South Sumatra athletes was carried out manually so that there were several weaknesses, namely 1) the results of the tests carried out were inaccurate, 2) it took a longer time to find out the results, 3) more human labor was needed. From some of the weaknesses of manual testing, it is necessary to design a test application model, so that it can be used as a guide by the coach to measure the 
physical abilities of athletes so that it can improve the quality of the physical components which ultimately increase the peak performance of athletes during the match.

According to the author's observations, the physical test for PON 2021 South Sumatra athletes was carried out manually so that there were several weaknesses, namely 1) the results of the tests carried out were inaccurate, 2) it took a longer time to find out the results, 3) more human labor was needed. From some of the weaknesses of manual testing, it is necessary to design a test application model, so that it can be used as a guide by the coach to measure the physical abilities of athletes so that it can improve the quality of the physical components which ultimately increase the peak performance of athletes during the match.

\section{Methods}

This research is development research and is a type of research used in solving practical problems in the field of sports. The opinion of Borg and Gall [8] that research and development is a process used to develop or validate products used in education. Then the opinion of Sugiono [9] argues that research and development methods are research methods used to produce certain products and test the effectiveness of the product.

This research was developed by modifying the research and development steps developed by Borg and Gall [8] including the following activities: (1) needs analysis, (2) developing initial products (3) conducting expert validation (4) conducting tests try small-scale and largescale fields (5) product revisions and (6) final products.

This research took place at the Sriwijaya University campus with a sample of 65 South Sumatra athletes, 10 trainers and 12 field test staff. Data analysis was carried out descriptively qualitatively and quantitatively. To find out the validity of the product developed, it was adapted from Dewi and Mashami [10], while to find out the practicality of the product developed using the criteria suggested by Saenab et al [11].

\section{Results}

After the product development model for the athlete's physical test application is tested on a small scale and then revised, the next step is to conduct trials on a large scale. The following is the research data:

\subsection{Model validation test results}

The final product is evaluated or assessed by 2 experts in their respective fields. The first validator is an expert lecturer in technology and the second validator is an expert lecturer in the field of sports coaching. The validation results can be presented in Table 1. 
Table 1. The results of the physical test application model validation.

\begin{tabular}{lll}
\hline Aspect & Average & Criteria \\
\hline The model suitable with the needs of sports tests & 3.83 & Valid \\
The model suitable with the form of a physical test & 3.92 & Valid \\
Ease of tools and model facilities to use & 3.89 & Valid \\
The model developed effectively measures the physical components of athletes & 4.00 & Very Valid \\
The model suitable with the athlete's physical test principles & 3.92 & Valid \\
Practicality of model developed & 3.92 & Valid \\
The model is developed according to technology & 3.67 & Valid \\
The model developed is easy to operationalize & 4.00 & Very Valid \\
The model developed improves physical test performance & 3.93 & Valid \\
The model developed makes the physical test time efficient & 4.00 & Very Valid \\
\hline
\end{tabular}

Based on the results of the validation carried out by two validators, it was found that the physical test application model met the criteria as a physical test model. In conclusion, from the data obtained, the physical test application model developed is valid so that it can be used in measuring the physical abilities of athletes.

\subsection{Model practicality test results}

The response of athletes to the implementation of the physical test application model can be applied in physical test activities, summarized in Table 2.

Table 2. The response of athletes to the physical test application model.

\begin{tabular}{lll}
\hline Aspect & Average & Criteria \\
\hline Ease of taking a physical test & 3.52 & Very Positive \\
Benefits of the physical test application model & 3.40 & Very Positive \\
Usability of the physical test application model & 3.59 & Very Positive \\
The model suitable with the form of a physical test & 3.52 & Very Positive \\
Efficiency and effectiveness model to measure the athlete's physical test ability & 3.49 & Very Positive \\
Mean & 3.50 & Very Positive \\
\hline
\end{tabular}

Table 2 describes the athlete's response to the application of the physical test application model, which received a very positive response with an average score of 3.50 .

\subsection{Physical test results for athletes using a physical test application model}

The results of the research on the aspects of explosive power, speed, agility, flexibility, and endurance (Vo2 max) on 65 athletes from South Sumatra. 
Table 3. The results of the athlete's physical test.

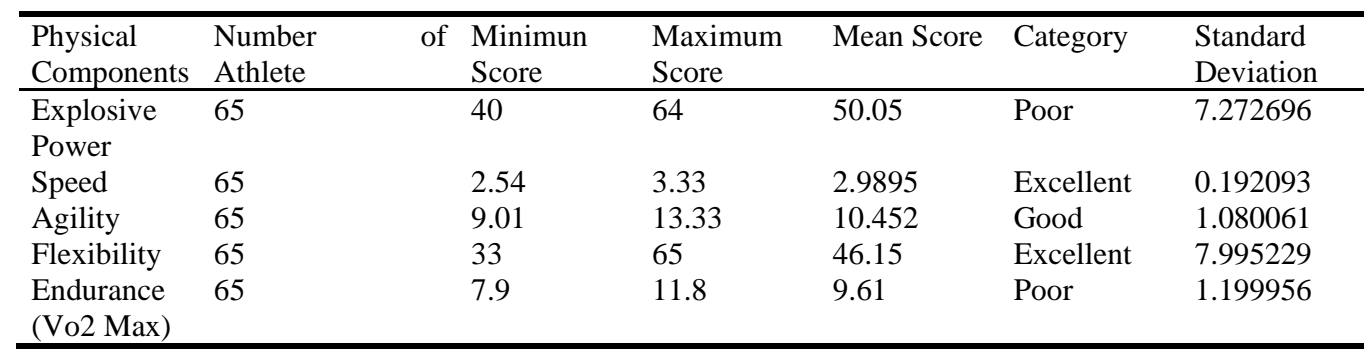

Based on the test results in table 3, the results of the test results for the power component mean score 50.05 in the poor category, the mean speed component of the mean score is 2.989 in the excellent category, the agility of the mean score is 10.45 in the good category, the flexibility of the mean score is 46.15 in the excellent category and endurance (Vo2max) mean score 9.61 with poor category.

\section{Discussion}

The physical test application model for athletes is in line with the opinion of Bompa, [12] that the test and form of physical exercise are highly dependent on the components of physical needs, so it is necessary to know the physical components needed for the sport. Then Fox's opinion [6] the conditioning stage is the first stage to start training in an exercise program and is arranged based on the results of the athlete's physical test. Then Iyakrus's research, [13] the physical test develops aspects that are in accordance with the needs of athletes in the field and will be able to support the athlete's appearance so as to create self-confidence during the competition.

Iyakrus's research [13] by conducting a physical test will determine the person's fitness level based on the data obtained from the test results, then based on the existing data the trainer can compile a targeted training program.

Research results from Lidor [14] through the test will obtain objective data about the physical condition of an athlete, then Nurhasan's opinion [15] that a good physical test is a test conducted based on the needs of the sport, while Widiastuti's opinion [16] test is a collection of information to measure about the physical condition so that you can find out the progress of the training done so far.

\section{Conclusions and suggestions}

Based on the analysis of the results of research on the development of a physical test application model, it can be concluded as follows: 1) the physical test application model is a test application based on the needs of the physical components of the sport and is designed in a series of tests to improve the quality of athlete training, 2) the application model Physical test has good validity and is very practical to use for athletes. The physical test application model as a product that has been produced in this study can be used as an alternative in measuring the physical components and improving the quality of athletic training. 


\section{References}

[1] Adyrkhaev SG. Modern Technology of Physical Education of Disabled Students in Conditions of Inclusive Education. Pedagogics, Psychology, Medical-Biological Problems of Physical Training and Sports. 2016; 20(01):4-12.

[2] Bompa TO. Periodization Training for Sports. $3^{\text {th }}$ Edition. United State of America: Human Kinetic; 2015.

[3] Bompa TO. Total Training for Young Champions. Champaign: Human Kinetics; 2009.

[4] Borg, Gall. Educational Research: An Introduction. $7^{\text {th }}$ Edition. University of Oregon and Utah State University; 2003.

[5] Dewi CA, Mashami RA. Journal of Turkish Science. 2019; 11(1): 3-23.

[6] Fox. Physiological Basis Of Physical Education and Athletics. $4^{\text {th }}$ Edition. Philadelphia: Ed Saunders Collage Publishing; 2009.

[7] Gibbs B, Quennerstedt M, Larsson H. Teaching Dance in Physical Education Using Exerfames. European Physical Education Review. 2016. 1-20.

[8] Haff G. George. Training Principles For Power. Centre For Exercise And Sport Science Research. 2012; 34 (6).

[9] Hartati, Aryanti S, Victorian AR. Development of Physical Test Applications Basketball Sports Model in Regional Student Education and Training Center. Proceedings of the International Conference on Progressive Education (ICOPE 2019); Lampung.

[10] Herguner G. Tablet Computer Literacy Levels of the Physical Education and Sports Department Students. Malaysian Online Journal of Educational Technology. 2016; 4(2):58-65.

[11] Hoppe DJ, Truntzer JN, Shapiro LM, Abrams GD, Safran MR. Diagnostic Accuracy of 3 Physical Examination Tests in the Assessment of Hip Microinstability. Orthopaedic Journal of Sports Medicine. 2017; 5(11).

[12] Hopper DM, Goh SC, Wentworth LA, Chan DYK, Chau JHW, Wootton GJ, Strauss GR, Boyle JJW. Test-retest reliability of knee rating scales and functional hop tests one year following anterior cruciate ligament reconstruction. Physical Therapy in Sport. 2002; 3(1): 10-18.

[13] Iyakrus. Model Test Fisik melalui Aplikasi. Palembang: Sriwijaya University; 2018.

[14] Lidor R, Falk B, Arnon M, Cohen Y, Segal G, Lander Y. Measurement Of Talent In Team Handball: The Questionable Use Of Motor And Physical Tests. Journal of Strength and Conditioning Research. 2005; 19(2): 318-325.

[15] Nurhasan. Tes dan Pengukuran dalam Pendidikan Jasmani. Jakarta: Depdiknas; 2009.

[16] Pate RR. Scientific Foundation of Coaching. New York: Saunders Collage Publishing; 1990. 